Arch. Tierz., Dummerstorf 45 (2002) 3, 279-285

University of Veterinary and Pharmaceutical Sciences, Brno, Czech Republic ${ }^{1}$

Mendel University of Agriculture and Forestry, Brno, Czech Republic ${ }^{2}$

EVA STRAKOVÁ ${ }^{1}$, PAVEL SUCHÝ ${ }^{1}$, VLADIMÍR VEČEREK ${ }^{1}$

and LADISLAV MÁCHAL ${ }^{2}$

\title{
The variation in amino acid levels in the blood plasma of breeding roosters during sexual maturation*
}

\section{Summary}

The paper provides an overview of results obtained in the study of variation in free amino acid levels in the blood plasma of breeding roosters (RIR 05 line) during sexual maturation (in the $10^{\text {th }}, 15^{\text {th }}, 20^{\text {th }}$ and $25^{\text {th }}$ weeks of age). The results prove that dynamic changes in free amino acid concentrations in blood plasma are connected with the sexual maturation of breeding roosters. During this period the concentrations of each particular free amino acid varied at a significance level of $\mathrm{P} \leq 0.05$ and $\mathrm{P} \leq 0.01$. Furthermore, in most cases the plasma concentrations of free amino acids in the $10^{\text {th }}$ and $15^{\text {th }}$ week were higher in comparison with those in the $20^{\text {th }}$ and $25^{\text {th }}$ week. Interestingly, the concentrations of individual free amino acids ranged over a wide interval (units, tens and hundreds of $\mu \mathrm{mol} / \mathrm{l}$ ). In this respect the free amino acids in plasma can be divided into three groups. The first group consisted of amino acids that occurred at low molar concentration (up to $100 \mu \mathrm{mol} / \mathrm{l}$ ): cysteic acid, aspartic acid, $\alpha$-aminoadipic acid, methionine, isoleucine, $\gamma$-aminobutyric acid, 3-methylhistidine, tryptophan and ornitine. The second group included amino acids occurring at medium to high molar concentration (100 $300 \mu \mathrm{mol} / \mathrm{l})$ : taurine, glutamine, $1 / 2$ cystine, valine, leucine, tyrosine, phenylalanine, histidine, lysine and arginine. Finally, the third group contained threonine, serine, glutamic acid, proline, glycine and alanine that were present at high molar concentrations (above $300 \mu \mathrm{mol} / \mathrm{l}$ ). Analyses of plasma in the period from the $10^{\text {th }}$ to $25^{\text {th }}$ week detected dynamic changes in levels of individual free amino acids and showed that the total content of these amino acids gradually decreased to the following mean values: $5685.00 \mu \mathrm{mol} / 1$ in the $10^{\text {th }}$ week, $5076.21 \mu \mathrm{mol} / 1$ in the $15^{\text {th }}$ week, $4384.78 \mu \mathrm{mol} / 1$ in the $20^{\text {th }}$ week and $4793.30 \mu \mathrm{mol} / 1$ in the $25^{\text {th }}$ week.

Key Words: rooster, sexual maturation, blood plasma, free amino acids

\section{Zusammenfassung}

Titel der Arbeit: Aminosäurespektrum im Blutplasma von Zuchthähnen im Laufe ihrer Geschlechtsreife Es wird über Untersuchungen zum Spektrum freier Aminosäuren von Hähnen der Linie RIR 05 im Laufe der Geschlechtsreifung (10., 15., 20. und 25. Lebenswoche) berichtet. Die Ergebnisse weisen auf eine dynamische Entwicklung der einzelnen im Plasma vorhandenen freien Aminosäuren im Zusammenhang mit der Geschlechtsreifung von Zuchthähnen hin. Die Konzentrationen der einzelnen freien Aminosäuren variierten bei unterschiedlichem Signifikanzniveau. In den meisten Fällen wurden in der 10. und 15. Woche höhere Konzentrationen als in der 20. und 25 Woche nachgewiesen. Bemerkenswert ist, dass es im Laufe der Geschlechtsreifung im Blutplasma zu einer signifikanten Schwankung der freien Aminosäuren in Größenordnungen von Einern, Zehnern und Hundertsteln $\mu \mathrm{mol} / 1$ Blutplasma kommt. Aus dieser Sicht kann das gesamte Spektrum von freien Aminosäuren im Blutplasma in drei Gruppen eingeteilt werden. Die erste Gruppe enthält freie Aminosäuren mit einer niedrigen molaren Konzentration von unter $100 \mu \mathrm{mol} / 1$ repräsentiert durch Zysteo-, Asparagin-, Aminoadip-, Methionin-, Isoleucin-, $\gamma$-Aminobuttersäure, 3-Methylhistidin, Tryptophan und Ornitin. Zur Gruppe der Aminosäuren mittel hoher molarer Konzentration von 100 bis $300 \mu \mathrm{mol} / 1$ zählen Taurin, Glutamin 1/2 Zystin, Valin, Leucin, Thyrosin, Phenylalanin, Histidin, Lysin und Arginin. Zur Gruppe mit einer molaren Konzentration von über $300 \mu \mathrm{mol} / 1$ zählen Threonin, Serin, Glutaminsäure, Prolin, Glycin und Alanin. Die Analysen beweisen, dass es im Laufe des Beobachtungszeitraumes außer einer dynamischen Veränderung bei den einzelnen freien Aminosäuren auch tendenziell zu einer schrittweisen Verringerung der Gesamtsumme der Aminosäuren im Blutplasma kommt. Die Durchschnittswerte der erfassten Aminosäurekonzentrationen betrugen in der 10. bis zur 20. Woche 5685,00, 5076,21, 4384,78 und 4793,30 $\mu \mathrm{mol} / 1$.

* This work is a part of Research Project no. 524/01/022 (GA CR), “Analysis of Free Plasmatic Amino Acids as Nutrition Markers and Their Effect on the Production of Domesticated Birds." 


\section{Introduction}

Saccharides, lipids and proteins are three basic components of human nutrition. Proteins are essential for living organisms as they enable anabolic processes and participate in the transformation of energy. However, diets are often deficient in proteins. Amino acids resulting from protein digestion are the major sources of nitrogen for an organism. Free amino acids and dipeptides are absorbed from the intestine. In blood they combine with amino acids released by degradation of tissue proteins or produced in protein biosynthesis to build a metabolic pool available for cells in all tissues.

The biological and nutrition values of poultry products are very high. Poultry meat represents an easily digestible nutrient with a high content of essential amino acids. The production of high-quality proteins depends upon comprehensive knowledge of the structures and effects of each particular amino acid. Undoubtedly, there are a large number of issues in this field to be addressed, for example the monitoring of amino acids levels in the blood plasma. Though a number of detailed studies have been carried out in large domestic animals, analogous data in poultry are sporadically reported. Thus, the majority of the basic physiological values in poultry are still unknown.

According to PROKOP (1991) a relatively high demand for feed by growing and highly productive poultry arises from enhanced protein biosynthesis, which is, from an energy point of view, the most demanding process in an organism. The metabolism in every organism requires all amino acids to be in a proper ratio. A disproportion in essential amino acids results in lowered utilization of other amino acids and leads to increasing demands for nitrogen substances in a feeding mixture. Such essential amino acids are termed "limiting" amino acids (ZELENKA et al., 1993).

PROKOP (1991) have reported that the current feeding mixtures for poultry are deficient in methionine. This amino acid participates not only in tissue building processes but also in the biosynthesis of antibodies. For example, it is capable of eliminating growth suppression caused by an excess of copper. Methionine deficiency results in increased intake of feedstuffs, inefficient utilization of nutrients and in inhibition of glycine absorption. Through its lipotropic effect, methionine affects physiological processes in the liver and controls the function of the thyroid gland.

Lysine is another essential amino acid. A deficiency of lysine in the diet causes growth suppression, the decrease of activity of transaminases and a high demand for oxygen by liver tissues (PROKOP,1991).

IORDÁNOVÁ (1980) studied variations in total protein levels, protein fractions and free amino acids in the blood plasma of chickens and pigs whose diet during growth was enriched in amino acids.

ZHORINA and STEPCHENKO (1991) monitored the content of free amino acids in the selected tissues of broilers which were fed with nitrogen humate.

The main aim of our research was to study the dynamics of free amino acids in the blood plasma of breeding roosters during sexual maturation in order to gain a deeper insight into the amino acid metabolism in this important period. 


\section{Materials and Methods}

The monitoring during the experiment was carried out in an approved animal enclosure at The Institute for Nutrition, Dietetics, Zoo-Hygiene and Food Crop Production at The University of Veterinary and Pharmaceutical Sciences in Brno.

10 breeding roosters (RIR 05 line) selected for the experiment were bedded in a cage with deep bedding. Over the whole monitoring period the respective zoohygienic and technological requirements for this breed of roosters were observed. The temperature was maintained from 15 to $18{ }^{\circ} \mathrm{C}$ and the light-day was adjusted according to the age of roosters as follows: 8 hours from $10^{\text {th }}$ to $20^{\text {th }}$ week, 9 hours in $20^{\text {th }}$ week, 9.5 hours in $21^{\text {st }}$ week, 10 hours in $22^{\text {nd }}$ week, 10.5 hours in $23^{\text {rd }}$ week, 11 hours in $24^{\text {th }}$ week and 11.5 hours in $25^{\text {th }}$ week. Tube plastic feeders and hanging drinkers (PLASSON MK II) were used for feeding. Roosters were fed ad libitum with a complex feeding mixture. According to our analyses the composition of the feeding mixture was as follows: $185.3 \mathrm{~g}$ of N-substances, $29.1 \mathrm{~g}$ of fat, $36.7 \mathrm{~g}$ of fiber, $55.9 \mathrm{~g}$ of ash, 12.45 MJ of metabolic energy, $11.3 \mathrm{~g}$ of $\mathrm{Ca}, 6.9 \mathrm{~g}$ of $\mathrm{P}$ and $1.9 \mathrm{~g}$ of $\mathrm{Mg}$ per $\mathrm{kg}$ dry matter.

The experimental monitoring of roosters was carried out in the period of their sexual maturation, i.e. from the $10^{\text {th }}$ to the $25^{\text {th }}$ weeks of age. In regular five-week intervals (between 7 and 8 a.m.) blood was taken from vena basilica and placed in test tubes coated with heparin. Blood plasma was immediately precipitated by the addition of $18 \%$ sulfosalicylic acid to remove proteins and prepare a sample for free amino acid analysis.

Free amino acids in the blood plasma of breeding roosters were determined by the widely known method of column chromatography using lithium citrate buffers and the AAA 339 (Mikrotechna Praha) automatic analyzer of amino acids.

Samples of blood plasma were assayed for the following amino acids ( $\mu \mathrm{mol} / \mathrm{l})$ : cysteic acid, taurine, aspartic acid, threonine, serine, glutamic acid, glutamine, $\alpha$-aminoadipic, proline, glycine, alanine, $1 / 2$ cystine, valine, methionine, isoleucine, leucine, tyrosine, phenylalanine, $\gamma$-aminobutyric acid, histidine, 3-methylhistidine, tryptophan, ornithine, lysine, arginine.

The results were worked up using mathematical and statistical methods by VENČIKOV and VENČIKOV (1977). All the presented results in tables are mean values (with standard deviation). The results obtained were calculated statistically according to the Student's T-test $\mathrm{P} \leq 0.05 *$ respectively $\mathrm{P} \leq 0.01 * *$.

\section{Results}

The results of amino acid analyses are shown in Tables 1-2.

The mean concentrations of cysteic acid during this period ranged from 12.30 to 19.19 $\mu \mathrm{mol} / 1$ with an inconclusive increase being detected from the $20^{\text {th }}$ to the $25^{\text {th }}$ week. The mean values for aspartic acid varied between 67.01 and $101.00 \mu \mathrm{mol} / 1$. A statistically significant difference $(\mathrm{P} \leq 0.05)$ was found for mean values in $20^{\text {th }}(77.37 \mu \mathrm{mol} / \mathrm{l})$ and in the $25^{\text {th }}$ week $(67.01 \mu \mathrm{mol} / 1)$. An interesting trend in mean concentrations of $\alpha$ aminoadipic acid was observed. The mean concentrations fell into a relatively wide interval spanning from $3.84 \mu \mathrm{mol} / 1$ (in $15^{\text {th }}$ week) to $21.67 \mu \mathrm{mol} / 1$ (in $10^{\text {th }}$ week). A statistically very significant $(\mathrm{P} \leq 0.01)$ decrease of the $\alpha$-aminoadipic acid concentration was detected in the $15^{\text {th }}$ week $(3.84 \mu \mathrm{mol} / \mathrm{l})$, while in the $20^{\text {th }}$ week the concentration rose conclusively to $10.90 \mu \mathrm{mol} / 1$. The mean concentration of methionine ranged from 49.02 to $65.19 \mu \mathrm{mol} / 1$ whereas in $25^{\text {th }}$ week it increased 
conclusively $(\mathrm{P} \leq 0.05)$ from $49.02 \mu \mathrm{mol} / 1$ to $59.87 \mu \mathrm{mol} / 1$. Isoleucine concentrations increased conclusively $(\mathrm{P} \leq 0.01)$ to $100.33 \mu \mathrm{mol} / 1$ in the $25^{\text {th }}$ week. The level of $\gamma$ aminobutyric acid increased significantly $(\mathrm{P} \leq 0.01)$ from $49.64 \mu \mathrm{mol} / 1$ in the $10^{\text {th }}$ week to $73.64 \mu \mathrm{mol} / 1$ in the $15^{\text {th }}$ week, which was followed by a conclusive decline (P $\leq 0.01)$ to $44.66 \mu \mathrm{mol} / 1$ in the $20^{\text {th }}$ week. Statistically significant differences $(\mathrm{P} \leq 0.05)$ in concentrations of plasmatic 3-methylhistidine were detected in the $15^{\text {th }}$ week $(31.29$ $\mu \mathrm{mol} / \mathrm{l}), 20^{\text {th }}$ week $(25.90 \mu \mathrm{mol} / \mathrm{l})$ and $25^{\text {th }}$ week $(34.11 \mu \mathrm{mol} / \mathrm{l})$. The increase of the mean concentrations of tryptophan from $60.69 \mu \mathrm{mol} / 1\left(10^{\text {th }}\right.$ week $)$ to $65.65 \mu \mathrm{mol} / 1\left(20^{\text {th }}\right.$

Table 1

Mean values of free amino acids with low molar concentrations (up to $100 \mu \mathrm{mol} / 1$ medium to high (100-300 $\mu \mathrm{mol} / \mathrm{l}$ ) and high molar concentrations (above $300 \mu \mathrm{mol} / \mathrm{l}$ ) in the blood plasma of breeding roosters in the period of sexual matura (Mittelwerte von freien Aminosäuren mit niedriger (bis $100 \mu \mathrm{mol} / \mathrm{l})$, mittlerer (100-300 $\mu \mathrm{mol} / \mathrm{l}$ ) und hoher (über $300 \mu \mathrm{mol} / \mathrm{l}$ ) Mol-Konzentration im Blutplasma von Zuchthähnen während der Periode ihrer Geschlechtsreife)

\begin{tabular}{|c|c|c|c|c|c|c|c|}
\hline \multirow[t]{2}{*}{ Amino acid } & \multicolumn{2}{|c|}{$10^{\text {th }}$ week } & \multicolumn{2}{|c|}{$15^{\text {th }}$ week } & \multicolumn{2}{|c|}{$20^{\text {th }}$ week } & \multirow{2}{*}{$\frac{25^{\text {th }} \text { week }}{\mu \mathrm{mol} / 1}$} \\
\hline & $\mu \mathrm{mol} / \mathrm{l}$ & $\mathrm{td}$ & $\mu \mathrm{mol} / 1$ & $\mathrm{td}$ & $\mu \mathrm{mol} / 1$ & $\mathrm{td}$ & \\
\hline \multicolumn{8}{|c|}{ Low molar concentrations (up to $100 \mu \mathrm{mol} / \mathrm{l}$ ) } \\
\hline Cysteic A. & $\begin{array}{l}16.89 \\
(7.79) \\
\end{array}$ & - & $\begin{array}{l}14.93 \\
(7.22) \\
\end{array}$ & - & $\begin{array}{r}12.30 \\
(6.94) \\
\end{array}$ & - & $\begin{array}{c}19.19 \\
(18.95)\end{array}$ \\
\hline Aspartic A. & $\begin{array}{l}101.00 \\
(21.27)\end{array}$ & - & $\begin{array}{c}89.57 \\
(18.54)\end{array}$ & - & $\begin{array}{l}77.37 \\
(9.52)\end{array}$ & * & $\begin{array}{c}67.01 \\
(10.67)\end{array}$ \\
\hline $\begin{array}{c}\alpha \text {-aminoadipic } \\
\text { acid }\end{array}$ & $\begin{array}{c}21.67 \\
(12.68) \\
\end{array}$ & ** & $\begin{array}{c}3.84 \\
(3.64)\end{array}$ & ** & $\begin{array}{l}10.90 \\
(6.42)\end{array}$ & - & $\begin{array}{l}12.49 \\
(4.89)\end{array}$ \\
\hline Methionine & $\begin{array}{c}65.19 \\
(13.74)\end{array}$ & - & $\begin{array}{l}54.53 \\
(9.86)\end{array}$ & - & $\begin{array}{c}49.02 \\
(14.83)\end{array}$ & * & $\begin{array}{l}59.87 \\
(8.57)\end{array}$ \\
\hline Isoleucine & $\begin{array}{c}94.09 \\
(24.10) \\
\end{array}$ & - & $\begin{array}{c}78.11 \\
(15.75)\end{array}$ & - & $\begin{array}{c}67.61 \\
(15.93)\end{array}$ & ** & $\begin{array}{l}100.33 \\
(18.83)\end{array}$ \\
\hline $\begin{array}{c}\gamma \text {-aminobutyric } \\
\text { acid }\end{array}$ & $\begin{array}{l}49.64 \\
(9.34) \\
\end{array}$ & ** & $\begin{array}{c}73.64 \\
(12.32) \\
\end{array}$ & ** & $\begin{array}{c}44.66 \\
(19.63) \\
\end{array}$ & - & $\begin{array}{c}48.05 \\
(19.15) \\
\end{array}$ \\
\hline $\begin{array}{l}\text { 3-methyl } \\
\text { histidine }\end{array}$ & $\begin{array}{l}25.48 \\
(6.42)\end{array}$ & * & $\begin{array}{l}31.29 \\
(5.04)\end{array}$ & * & $\begin{array}{l}25.90 \\
(5.28)\end{array}$ & * & $\begin{array}{l}34.11 \\
(7.95)\end{array}$ \\
\hline Tryptophan & $\begin{array}{c}60.69 \\
(12.50) \\
\end{array}$ & - & $\begin{array}{c}65.79 \\
(12.80) \\
\end{array}$ & - & $\begin{array}{c}65.65 \\
(14.70) \\
\end{array}$ & ** & $\begin{array}{l}50.44 \\
(6.31) \\
\end{array}$ \\
\hline Ornithine & $\begin{array}{c}51.48 \\
(17.86)\end{array}$ & ** & $\begin{array}{l}27.90 \\
(10.97)\end{array}$ & ** & $\begin{array}{l}33.39 \\
(8.76)\end{array}$ & * & $\begin{array}{c}79.67 \\
(31.53) \\
\end{array}$ \\
\hline \multicolumn{8}{|c|}{ Medium to high molar concentration $(100-300 \mu \mathrm{mol} / \mathrm{l})$} \\
\hline Taurine & $\begin{array}{l}158.06 \\
(75.19) \\
\end{array}$ & * & $\begin{array}{c}99.69 \\
(39.47)\end{array}$ & - & $\begin{array}{c}87.72 \\
(18.61)\end{array}$ & - & $\begin{array}{l}112.60 \\
(42.56)\end{array}$ \\
\hline Glutamine & $\begin{array}{l}120.54 \\
(28.57) \\
\end{array}$ & - & $\begin{array}{l}152.19 \\
(43.43) \\
\end{array}$ & - & $\begin{array}{l}123.16 \\
(33.82) \\
\end{array}$ & ** & $\begin{array}{l}205.48 \\
(34.85) \\
\end{array}$ \\
\hline $1 / 2$ cystine & $\begin{array}{l}112.81 \\
(24.58) \\
\end{array}$ & - & $\begin{array}{l}124.96 \\
(19.31) \\
\end{array}$ & - & $\begin{array}{l}121.94 \\
(27.53) \\
\end{array}$ & - & $\begin{array}{l}144.39 \\
(21.42) \\
\end{array}$ \\
\hline Valine & $\begin{array}{l}210.95 \\
(53.17) \\
\end{array}$ & * & $\begin{array}{l}165.60 \\
(33.51)\end{array}$ & - & $\begin{array}{l}151.67 \\
(46.60)\end{array}$ & ** & $\begin{array}{l}247.58 \\
(42.84) \\
\end{array}$ \\
\hline Leucine & $\begin{array}{l}201.32 \\
(32.28)\end{array}$ & - & $\begin{array}{l}196.87 \\
(45.34)\end{array}$ & - & $\begin{array}{l}164.09 \\
(30.82)\end{array}$ & * & $\begin{array}{l}205.84 \\
(36.41)\end{array}$ \\
\hline Tyrosine & $\begin{array}{l}156.78 \\
(21.71)\end{array}$ & * & $\begin{array}{l}204.31 \\
(57.89)\end{array}$ & ** & $\begin{array}{l}137.30 \\
(29.24)\end{array}$ & - & $\begin{array}{l}129.02 \\
(32.96)\end{array}$ \\
\hline Phenylalanine & $\begin{array}{l}104.98 \\
(15.66)\end{array}$ & ** & $\begin{array}{l}128.70 \\
(15.62)\end{array}$ & *** & $\begin{array}{c}81.62 \\
(15.00)\end{array}$ & - & $\begin{array}{l}87.58 \\
(8.96)\end{array}$ \\
\hline Histidine & $\begin{array}{l}108.26 \\
(9.47) \\
\end{array}$ & ** & $\begin{array}{l}135.79 \\
(36.91)\end{array}$ & * & $\begin{array}{c}92.45 \\
(31.00) \\
\end{array}$ & - & $\begin{array}{r}106.59 \\
(17.56) \\
\end{array}$ \\
\hline Lysine & $\begin{array}{l}295.21 \\
(56.63)\end{array}$ & ** & $\begin{array}{c}86.88 \\
(29.67)\end{array}$ & ** & $\begin{array}{l}177.59 \\
(64.52)\end{array}$ & * & $\begin{array}{l}288.02 \\
(78.08)\end{array}$ \\
\hline Arginine & $\begin{array}{l}214.57 \\
(46.05)\end{array}$ & - & $\begin{array}{l}167.27 \\
(89.61)\end{array}$ & - & $\begin{array}{l}139.02 \\
(68.33) \\
\end{array}$ & - & $\begin{array}{l}174.92 \\
(90.00)\end{array}$ \\
\hline
\end{tabular}


Table 1 (Continuation)

\begin{tabular}{|c|c|c|c|c|c|c|c|}
\hline \multirow[t]{2}{*}{ Amino acid } & \multicolumn{2}{|c|}{$10^{\text {th }}$ week } & \multicolumn{2}{|c|}{$15^{\text {th }}$ week } & \multicolumn{2}{|c|}{$20^{\text {th }}$ week } & \multirow{2}{*}{$\frac{25^{\text {th }} \text { week }}{\mu \mathrm{mol} / 1}$} \\
\hline & $\mu \mathrm{mol} / 1$ & $\mathrm{Td}$ & $\mu \mathrm{mol} / 1$ & td & $\mu \mathrm{mol} / 1$ & td & \\
\hline \multicolumn{8}{|c|}{ High molar concentration (above $300 \mu \mathrm{mol} / \mathrm{l}$ ) } \\
\hline Threonine & $\begin{array}{c}815.91 \\
(134.49)\end{array}$ & $* *$ & $\begin{array}{c}507.22 \\
(171.90)\end{array}$ & - & $\begin{array}{c}655.85 \\
(203.37)\end{array}$ & - & $\begin{array}{c}648.31 \\
(146.38)\end{array}$ \\
\hline Serine & $\begin{array}{l}493.95 \\
(93.42)\end{array}$ & - & $\begin{array}{c}455.45 \\
(113.05)\end{array}$ & - & $\begin{array}{l}362.15 \\
(92.12)\end{array}$ & - & $\begin{array}{l}313.54 \\
(42.74)\end{array}$ \\
\hline Glutamic acid & $\begin{array}{l}750.44 \\
(83.20)\end{array}$ & $* *$ & $\begin{array}{c}597.44 \\
(117.03)\end{array}$ & - & $\begin{array}{l}549.73 \\
(58.95)\end{array}$ & $* *$ & $\begin{array}{l}485.28 \\
(41.15)\end{array}$ \\
\hline Proline & $\begin{array}{l}442.55 \\
(93.78)\end{array}$ & $* *$ & $\begin{array}{c}586.87 \\
(210.62)\end{array}$ & - & $\begin{array}{l}356.64 \\
(99.02)\end{array}$ & - & $\begin{array}{l}435.42 \\
(97.42)\end{array}$ \\
\hline Glycine & $\begin{array}{l}491.38 \\
(57.45)\end{array}$ & - & $\begin{array}{l}488.04 \\
(89.40)\end{array}$ & - & $\begin{array}{l}432.06 \\
(83.24)\end{array}$ & - & $\begin{array}{l}467.84 \\
(65.76)\end{array}$ \\
\hline Alanine & $\begin{array}{l}521.16 \\
(84.76)\end{array}$ & - & $\begin{array}{c}539.33 \\
(144.95)\end{array}$ & $* *$ & $\begin{array}{l}364.99 \\
(67.42)\end{array}$ & $*$ & $\begin{array}{l}269.76 \\
(84.69)\end{array}$ \\
\hline
\end{tabular}

Table 2

Total content of free amino acids monitored in blood plasma of breeding roosters during the period of sexual maturation (Gesamtgehalt von freien Aminosäuren im Blutplasma von Hähnen während der Periode ihrer Geschlechtsreife)

\begin{tabular}{ccccc}
\hline Amino acids & $10^{\text {th }}$ week & $15^{\text {th }}$ week & $20^{\text {th }}$ week & $25^{\text {th }}$ week \\
\hline$\mu \mathrm{mol} / 1$ & 5685.00 & 5076.21 & 4384.78 & 4793.30 \\
Percent & 100 & 89.29 & 77.13 & 84.31 \\
\hline
\end{tabular}

week) was statistically inconclusive, but it was followed by a statistically significant $(\mathrm{P} \leq 0.01)$ decrease to $50.44 \mu \mathrm{mol} / 1$ in $25^{\text {th }}$ week. Ornithine levels varied between $27.90 \mu \mathrm{mol} / 1$ and $79.67 \mu \mathrm{mol} / 1$ over the whole period, reaching the maximum in the $25^{\text {th }}$ week. The most significant $(\mathrm{P} \leq 0.01)$ difference was found between ornithine concentrations in the $10^{\text {th }}$ week $(51.48 \mu \mathrm{mol} / \mathrm{l})$ and the $15^{\text {th }}$ week $(27.90 \mu \mathrm{mol} / \mathrm{l})$ and between the $15^{\text {th }}$ week $(27.90 \mu \mathrm{mol} / 1)$ and the $20^{\text {th }}$ week $(33.39 \mu \mathrm{mol} / \mathrm{l})$. In addition, the difference between the concentrations in the $20^{\text {th }}(33.39 \mu \mathrm{mol} / 1)$ and $25^{\text {th }}(79.67$ $\mu \mathrm{mol})$ weeks was also statistically significant $(\mathrm{P} \leq 0.05)$ (Table 1$)$.

The mean concentrations of taurine ranged from 87.72 to $158.06 \mu \mathrm{mol} / 1$. A statistically conclusive difference $(\mathrm{P} \leq 0.05)$ was found between taurine levels in the $10^{\text {th }}$ and $15^{\text {th }}$ weeks. The mean concentrations of glutamine during the period of sexual maturation varied in range from 120.54 to $205.48 \mu \mathrm{mol} / 1$, exhibiting a significant $(\mathrm{P} \leq 0.01)$ increase $205.48 \mu \mathrm{mol} / 1$ in the $25^{\text {th }}$ week. Statistically insignificant changes $(112.81-$ $144.39 \mu \mathrm{mol} / 1)$ were noticed for $1 / 2$ cystine during the period of roosters' sexual maturation. The mean concentrations of valine ranged from $151.67 \mu \mathrm{mol} / 1$ in the $20^{\text {th }}$ week to $247.58 \mu \mathrm{mol} / 1$ in the $25^{\text {th }}$ week. A significant $(\mathrm{P} \leq 0.05)$ decrease of valine levels to $165.60 \mu \mathrm{mol} / 1 \mathrm{in} 15^{\text {th }}$ week and a very conclusive $(\mathrm{P} \leq 0.01)$ increase to $247.58 \mu \mathrm{mol} / 1$ in the $25^{\text {th }}$ week was detected. Leucine concentrations increased conclusively $(\mathrm{P} \leq 0.05)$ from $164.09 \mu \mathrm{mol} / 1\left(20^{\text {th }}\right.$ week) to $205.84 \mu \mathrm{mol} / 1\left(25^{\text {th }}\right.$ week $)$. Mean concentrations of tyrosine showed a statistically significant $(\mathrm{P} \leq 0.05)$ increase from $156.78 \mu \mathrm{mol} / 1$ in the $10^{\text {th }}$ week to $204.31 \mu \mathrm{mol} / 1$ in the $15^{\text {th }}$ week, followed by a statistically significant $(\mathrm{P} \leq 0.01)$ decline to $137.30 \mu \mathrm{mol} / 1$ in the $20^{\text {th }}$ week. Mean concentrations of fenylalanine ranged from $81.62 \mu \mathrm{mol} / 1$ to $128.70 \mu \mathrm{mol} / \mathrm{l}$. Between the $10^{\text {th }}$ and $15^{\text {th }}$ weeks a highly significant $(\mathrm{P} \leq 0.01)$ increase of its mean concentrations (from $104.98 \mu \mathrm{mol} / 1$ to $128.70 \mu \mathrm{mol} / \mathrm{l}$ ) was observed, which was followed by a statistically significant $(\mathrm{P} \leq 0.01)$ decrease to $81.62 \mu \mathrm{mol} / 1$ in the $20^{\text {th }}$ 
week. Histidine concentrations showed a statistically significant $(\mathrm{P} \leq 0.01)$ variation from $108.26 \mu \mathrm{mol} / 1$ in the $10^{\text {th }}$ week to $135.79 \mu \mathrm{mol} / 1$ in the $15^{\text {th }}$ week, followed by a significant $(\mathrm{P} \leq 0.05)$ decrease to $92.45 \mu \mathrm{mol} / 1$ in the $20^{\text {th }}$ week. Highly significant changes $(\mathrm{P} \leq 0.01)$ were detected between lysine concentrations in the $10^{\text {th }}$ and $15^{\text {th }}$ weeks $(295.21-86.88 \mu \mathrm{mol} / \mathrm{l})$ and in the $15^{\text {th }}$ and $20^{\text {th }}$ weeks $(86.88-177.59 \mu \mathrm{mol} / \mathrm{l})$. Furthermore, a statistically significant $(\mathrm{P} \leq 0.05)$ variation in lysine levels was found between the $20^{\text {th }}$ and $25^{\text {th }}$ weeks $(177.59-288.02 \mu \mathrm{mol} / 1)$. In the case of arginine, a statistically inconclusive decrease of its mean concentration from $214.57 \mu \mathrm{mol} / 1\left(10^{\text {th }}\right.$ week) to $139.02 \mu \mathrm{mol} / 1\left(20^{\text {th }}\right.$ week $)$ was detected, followed by a statistically insignificant increase to $174.92 \mu \mathrm{mol} / 1$ in the $25^{\text {th }}$ week (Table 1).

The mean values of threonine in plasma were in the range from 507.22 to 815.91 $\mu \mathrm{mol} / 1$, showing a statistically significant $(\mathrm{P} \leq 0.01)$ decrease in the $15^{\text {th }}$ week. Serine levels exhibited an inconclusive decrease from $493.95 \mu \mathrm{mol} / 1$ in the $10^{\text {th }}$ week to $313.54 \mu \mathrm{mol} / 1$ in the $25^{\text {th }}$ week. In the case of glutamic acid, a statistically significant decrease $(\mathrm{P} \leq 0.01)$ of its concentration to $597.44 \mu \mathrm{mol} / 1$ and $485.28 \mu \mathrm{mol} / 1$ was detected in the $15^{\text {th }}$ week and in the $25^{\text {th }}$ week, respectively. The mean concentrations of proline ranged between 356.64 and $586.87 \mu \mathrm{mol} / \mathrm{l}$. The difference between its mean concentrations in the $10^{\text {th }}$ week $(442.55 \mu \mathrm{mol} / \mathrm{l})$ and the $15^{\text {th }}$ week $(586.87 \mu \mathrm{mol} / \mathrm{l})$ was statistically significant $(\mathrm{P} \leq 0.01)$. The mean concentrations of glycine $(432.06-$ $491.38 \mu \mathrm{mol} / \mathrm{l})$ during sexual maturation varied inconclusively. The difference between alanine levels in the $15^{\text {th }}(539.33 \mu \mathrm{mol} / \mathrm{l})$ and in the $20^{\text {th }}(364.99 \mu \mathrm{mol} / \mathrm{l})$ week was statistically significant $(\mathrm{P} \leq 0.01)$. A significant $(\mathrm{P} \leq 0.05)$ difference was also detected between the concentration in the $20^{\text {th }}$ week $(364.99 \mu \mathrm{mol} / \mathrm{l})$ and that in the $25^{\text {th }}(269.76 \mu \mathrm{mol} / \mathrm{l})$ week (Table 1$)$.

\section{Discussion}

Until now no papers on the monitoring of free amino acid concentrations in the blood plasma of breeding roosters during sexual maturation have been published - either in Czech or foreign journals. Some authors have studied variations in amino acid levels in relation to a particular element or synthetic amino acids or in connection with parasitic diseases.

GERGELYIOVÁ (1983) reported concentration values for some of amino acids in the blood plasma of turkey (essential amino acids: „phenylalanine“- $0.5 \mathrm{mg} / 100 \mathrm{ml}$, „threonine“- $5.5 \mathrm{mg} / 100 \mathrm{ml}$; non-essential amino acids: „,asparagine“ $0.8 \mathrm{mg} / 100 \mathrm{ml}$, „serine“": $6.5 \mathrm{mg} / 100 \mathrm{ml})$. STODOLA and ŘEHOUT (1988) monitored the dynamics of changes in molar concentrations of free plasmatic amino acids in calves over one year and demonstrated that free amino acids in the blood plasma of calves ranged from 6 to $300 \mu \mathrm{mol} / 1$. According to our results, the mean concentrations of free plasmatic amino acids varied from 3.84 to $815.91 \mu \mathrm{mol} / \mathrm{l}$. Thus, the amino acid levels in breeding roosters are higher than those determined in mammals. The variation in free plasmatic amino acids in sheep was studied by TOMÁŠ and MICHNOVÁ (1983).

Aminoanalysis of the blood plasma of breeding roosters during sexual maturation showed that in most cases the molar concentrations in roosters were higher than those reported for mammals.

One interesting finding is that amino acid levels in blood plasma not only varied conclusively but ranged over a very wide interval (in units, tens and hundreds of $\mu \mathrm{mol} / \mathrm{l})$. In this respect free plasmatic amino acids can be divided into three groups. 
The first group consisted of amino acids that occurred at low molar concentrations (up to $100 \mu \mathrm{mol} / \mathrm{l})$ : cysteic acid, aspartic acid, $\alpha$-aminoadipic acid, methionine, isoleucine, $\gamma$-aminobutyric acid, 3-methylhistidine, tryptophan and ornithine (Table 1). The second group included amino acids occurring at medium to high molar concentrations $(100-300 \mu \mathrm{mol} / 1$ ): taurine, glutamine, $1 / 2$ cystine, valine, leucine, tyrosine, phenylalanine, histidine, lysine and arginine (Table 1). Finally, the third group contained threonine, serine, glutamic acid, proline, glycine and alanine that were present at high molar concentrations (above $300 \mu \mathrm{mol} / \mathrm{l}$ ) (Table 1).

Analyses of plasma in the period from the $10^{\text {th }}$ to the $25^{\text {th }}$ week detected dynamic changes in levels of individual free amino acids and showed that the total content of these amino acids gradually decreased to the following mean values: 5,685.00 $\mu \mathrm{mol} / 1$ in $10^{\text {th }}$ week, $5,076.21 \mu \mathrm{mol} / 1$ in $15^{\text {th }}$ week, $4,384.78 \mu \mathrm{mol} / 1$ in $20^{\text {th }}$ week and $4,793.30$ $\mu \mathrm{mol} / \mathrm{l}$ in $25^{\text {th }}$ week (Table 2 ).

This paper provides new physiological data on domestic fowls and demonstrates the dynamic changes occurring in the blood plasma of breeding roosters during sexual maturation.

\section{GERGELYIOVÁ, V.:}

\section{References}

The effect of feeding mixtures enriched in L-lysine on utilization and the dynamics of free amino acids in turkeys during the egg-laying period. Biolog. chem. Vet., Praha, (1983), 547-551

IORDÁNOVÁ, V.:

Total protein, protein fraction and free amino acid changes in the blood serum of chicks and pigs raised with supplementary amounts of amino acids. Vet. med. Nauki, 17 (1980), 33-41

PROKOP, V.:

Nutrition consultation. Mze ČR, Praha, 390s. 1991

STODOLA, J.; ŘEHOUT, V.:

Seasonal variation in free amino acid levels in the blood plasma of calves. Živoč. Výr., 33 (1988), 481489

TOMÁŠ, V.; MICHNOVÁ, E.:

Free amino acid concentrations in the blood plasma of sheep with different intake of nitrogen substances. Vet. Med., 28 (1983), 339-345

VENČIKOV, A.I.; VENČIKOV, V.A.:

Basic methods of statistical data processing in physiology. Praha, Avicenum. 1977

ZELENKA, J.; ZEMAN, L.; KOČÍ, Š.; KOČÍOVÁ, Z.:

Nutrition requirements and tables of nutritional values of poultry feedstuff. ČAZV, 5-6. 1993

ZHORINA, L.V.; STEPCHENKO, L.M.:

The content of free amino acids in the tissues of broiler chicks following administration of humate in the ration. Nauchnye Dobi Vyss Shkoly Biol. Nauki, 10 (1991), 147-150

Received: 2001-10-19

Accepted: 2002-04-12

Author's addresses

Ing. EVA STRAKOVÁ, Ph.D., Prof. MV Dr. Ing. PAVEL SUCHÝ, CSc.,

Doc. MV Dr. VLADIMÍR VEČEREK, CSc.

University of Veterinary and Pharmaceutical Sciences, Brno

Faculty of Veterinary Hygiene and Ecology

Palackého 1/3, 61242 Brno

Czech Republic e-mail: strakovae@,vfu.cz

Doc. Ing. LADISLAV MÁCHAL, Dr Sc.

Mendel University of Agriculture and Forestry, Brno

Faculty of Agronomy

Zemědělská 1, 61300 Brno / Czech Republic 